\title{
History Learning through Online Learning During COVID-19 Pandemic: Teachers and Students Respond
}

\author{
Jamiludin $^{1}$, Darnawati \\ Department of History Education, Universitas Halu Oleo, Indonesia. \\ *Corresponding email: jamiluddin@uho.ac.id
}

Received: 28 February 2021

Accepted: 18 March 2021

Published: 19 March 2021

Abstract: History Learning through Online Learning During Covid-19 Pandemic: Teachers and Students Respond. Objectives: this study aims to know history learning during the COVID19 Pandemic, know the teachers and students respond, and see the e-learning applications that are most often used and how do students respond to use the application. Method: this research used a mixed-method approach. Result: this study showed that history learning experienced differences, and there were also similarities in understanding. The difference was that initially, the teacher used face-to-face learning methods, then online learning changes that rely on internet-based applications. Not having facilities such as smartphones, laptops, and internet networks that did not support learning, made some students unactive. $55.6 \%$ of history teachers chose Google Classroom, and $44.4 \%$ selected WhatsApp as an e-learning application in teaching. Conclusion: history teachers and students faced some challenges through online learning but they still can conduct the teaching and learning process.

Keywords: History Learning, Online Learning, COVID-19, E-learning Applications

Abstrak: Pembelajaran Sejarah melalui Pembelajaran Online Selama Pandemi Covid-19: Respon Guru dan Siswa. Tujuan: penelitian ini bertujuan untuk mengetahui pembelajaran sejarah selama pandemi COVID-19, mengetahui respon guru dan siswa, serta melihat aplikasi e-learning yang paling sering digunakan dan bagaimana respon siswa dalam menggunakan aplikasi tersebut. Metode: penelitian ini menggunakan pendekatan metode campuran. Hasil: penelitian ini menunjukkan bahwa pembelajaran sejarah mengalami perbedaan, dan terdapat kesamaan pemahaman. Perbedaannya, pada awalnya guru menggunakan metode pembelajaran tatap muka, kemudian perubahan pembelajaran online yang mengandalkan aplikasi berbasis internet. Tidak adanya fasilitas seperti smartphone, laptop, dan jaringan internet yang tidak mendukung pembelajaran membuat sebagian siswa tidak aktif. 55,6\% guru sejarah memilih Google Kelas, dan 44,4\% memilih WhatsApp sebagai aplikasi e-learning. Kesimpulan: guru dan siswa sejarah menghadapi beberapa tantangan melalui pembelajaran online tetapi mereka tetap dapat melakukan proses belajar mengajar.

Kata Kunci: Pembelajaran Sejarah, Pembelajaran Online, COVID-19, Aplikasi E-learning.

\section{To cite this article:}

Jamiludin \& Darnawati. (2020). History Learning through Online Learning During COVID-19 Pandemic: Teachers and Students Respond. Jurnal Pendidikan Progresif, 11(1), 12-26. doi: 10.23960/ jpp.v11.i1.202102. 


\section{INTRODUCTION}

Corona Virus Disease (COVID-19) pandemic has brought significant changes in the world. Since early March 2020, various policies have been issued by the central and local governments: starting from limiting social distancing, working from home, organizing online learning, eliminating worship activities, and asking people to stay at home, and reducing economic activities outside the home (Abidah, Hidaayatullaah, Simamora, Fehabutar, \& Mutakinati, 2020).

The policy is well-intentioned, but the policy's impact has a high risk, especially in education. In Indonesia, the teaching and learning process, which usually takes place offline, has turned into online learning (Hapsari Sinta Maulida, Sugito, 2020; Valverde-Berrocoso, del Carmen Garrido-Arroyo, Burgos-Videla, \& MoralesCevallos, 2020). This is supported by the Directorate General of Higher Education, urging universities to provide flexibility to conduct distance learning during the COVID-19 pandemic (Yulandari, 2020).

Schools were asked to promote homebased learning using various digital platforms and private channels that provide free-range content and opportunities for online learning across the country (Fund, 2020). The crisis should force institutions to embrace the new technologies, which were previously resistant to adapt. When the students practice after reading the material, few students in the learning process do not achieve its full knowledge. Online material is often abstract and does not support students to study and practice (Dhawan, 2020).

Besides government policies for regions, including red zone areas, schools organize learning activities from home. At the same time, schools that are in the green zone can organize learning activities from school. However, the middle school that is in the green area is now rarely found. Most schools are conducting online learning. One of them is in Southeast Sulawesi province, one of the provinces that has felt the Pandemic impact.

Based on the government's official letter, the teaching and learning process can still be conducted during the Pandemic. Schools must find solutions so that learning can always be carried out. Hence, the rights and obligations of students are even fulfilled, namely gaining knowledge and learning. Besides, teachers can carry out their responsibilities, namely teaching and educating students.

School behavior and habits during a pandemic are then regulated and transformed through virtual interactions. This condition also emphasizes that technology's function is essential as an intermediary for social interaction for the community, especially at schools during the current Pandemic. In the school environment, teachers must take advantage of technology by conducting online learning what teachers can do in designing online learning processes (Priatna, Maylawati, Sugilar, \& Ramdhani, 2020). The devices used to support this activity are computers or laptops, smartphones, and the internet package.

The use of technology in different ways helps teachers: (1) to improve course creation, and delivery methods-Software is used; (2) to help teachers use their teaching time more efficiently; (3) to monitor students' work by using the software; and (4) teachers can get many resources. When using technology students, have three different choices for delivering the same course: blended learning, completely online, and face-to-face mode. Therefore, all various study types may be included in the same course material (Hamiti \& Reka, 2012).

Some of the learning media that can be used are learning applications that can be downloaded 
for free. Namely, WhatsApp, Google Classroom, Zoom, and so on. Through this application, teachers can upload material in the form of power points or videos, give assignments, and discuss with students. Likewise, students can access material from the teacher online and submit the assignment. Therefore, the teaching and learning process can still run well.

The teaching problems that appeared were: the difficulty of teachers using technology (Anggraeni \& Suharso, 2019), the role of school facilities in supporting e-learning, the difficulties in explaining content, students' difficulty in accessing the Internet, students' economically disadvantaged family background, and the support network for parents. Nonetheless, during this COVID-19 outbreak, the teachers expressed that the e-learning program relieves their duty in carrying out the teaching and learning process (Lestiyanawati \& Widyantoro, 2020). Besides, both students' learning needs and urgent social studies subjects are taken into account in the webinar. Therefore, the social studies teachers use advance organizers with their explanations so that all students can stay on the same page (Torrau, 2020).

Based on the effect of the COVID-19 Pandemic on education, the ability to self-regulate is what you learn when you study at home. To facilitate your self-regulated learning at home, the following experiences are identified : (1) Juggling learning and play; (2) Selecting on-demand learning resources; (3) Drawing inspiration for research from play; (4) Engaging in self-monitoring learning (5) Improving e-assessment learning abilities; (6) Reflecting on learning methods; and (7) Exercising daily learning methods (Huang et al., 2020).

As for one of the subjects that need special attention, namely history learning. It is a process of interaction between students and their environment. The resulting changes in behaviour is a result of their interaction with studying history. History learning can help students understand human behaviour in the past, present, and future (Zahro, Sumardi, \& Marjono, 2017; Prastowo, In, \& Suryadi, 2019). History learning is memorizing and reminiscing about past history events. Still, history learning has the aim so that students can develop competencies to think chronologically and have past knowledge to understand and explain development and change in societies with socio-cultural diversity. Besides, in this present Pandemic, students can realize past pandemic that had ever been faced and impacted the community. They can bring about empathy and the right understanding to society.

Two factors need to be highlight about history learning. First, history learning studies are very closely related to social learning with society. Activities related to community problems that require direct involvement, such as field observations, are hampered. So that social presence between teachers and students is needed; hence social interaction occurs. Second, in normal situations, students' interest in learning is low (Ratri, Bain, \&Amin, 2017), so this learning gets very little attention from students. This is because history learning is boring, there are too many memorizations, and the learning methods are less creative. Therefore, this makes researchers want to know how history learning is during the Pandemic.

Some previous studies researched the impact of the COVID-19 Pandemic on education. Most of the researches aimed at explaining the impact of the coronavirus on teaching and learning activities, and also the perspectives of the students (Zaharah, Kirilova, and Windarti, 2020; Adnan \& Anwar, 2020; Torrau, 2020; Besand, 2020). Contrary, this research aims to find out the history learning during 
the COVID-19 Pandemic, describing the most used online applications and students respond. Some research questions in this study:

1. How is the history learning through online learning during COVID-19?

2. What are the students respond through online learning?

3. What is E-learning applications most often used during study from home?

\section{- METHODS}

This was a mixed-method approach that designed the study. Both quantitative and qualitative analyses are essential for researchers to learn and qualitatively allow a thorough exploration of a few people, the quantitative data provided by a large number of the people, and generalized results (Creswell, 2012). The subject of this study was 19 history teachers in Kendari, Southeast Sulawesi and 22 students of Senior High School.

Because of social distancing, the researcher tried to get the data by using Google Form. The steps were collecting numbers of history teachers in South East Sulawesi, making a WhatsApp group, giving questionnaires to the history teachers, asking to fill out the questionnaires using Google Form, and randomly giving questionnaires to students. After that, the researchers interviewed some history teachers.

Research instruments were questionnaire and interview. The questionnaire for history teachers contained two parts. The questionnaire consisted of part I. Open-Discussion questions and part II. Yes/ No questions and Multiple Choices. Part I had ten problems divided into two subparts: 1. history learning through online learning during the COVID-19 Pandemic; and 2. students respond during the study from home. Part II had twenty-seven questions about students' responses to using the E-learning application. One Multiple Choice about Elearning applications is most often used during the study from home. The interview showed more in-depth information. The question of the interview was based on the following aspects: the experience of history teachers during COVID19 Pandemic; and preference of history teachers and students, Online learning, or face to face model.

The procedures of data collection were: (1) Researchers prepared instruments such as questionnaires and guideline personal interviews. (2) The researcher asked the participants to accomplish the questionnaires for a week by using Google Form. After that, the teachers also have a personal interview by using WhatsApp. The researcher involved 19 history teachers and 22 students who had filled the questionnaires. (3) The researcher analysed data quantitative based on the questionnaires and data qualitative from the interview, documentation, field note, and audiovisual materials.

The researcher used descriptive statistics programs for computing the questionnaire analysis using SPSS (Statistical Package for the Social Sciences) 16 Program for Windows.

\section{RESULTS AND DISCUSSION}

This research used explanatory design which is part ofmixed method design (Cresswell, Plano Clark, Gutmann, \& Hanson, 2003). The overarching goal of explanatory design is to use qualitative data to justify or expand on quantitative findings.

Therefore, in this research used quantitative analysis of questionnaires first, then followed up by qualitative analysis (questionnaires and interviews). Below was the result of quantitative data. 
Table 1. Results of E-Learning Application Most Used in History Learning

\begin{tabular}{llcrr}
\hline \multicolumn{4}{c}{ Q4 } \\
\hline \multirow{4}{*}{ Valid } & Frequency & Percent & $\begin{array}{c}\text { Valid } \\
\text { Percent }\end{array}$ \\
\cline { 3 - 4 } & & 8 & 44.4 & 44.4 \\
& WhatsApp & 10 & 55.6 & 55.6 \\
& Google & & & \\
& Classroom & 18 & 100.0 & 100.0 \\
\hline
\end{tabular}

Table 1 shows the result of questionnaire number 4: What e-learning applications are used at history learning? The options are Google Classroom, WhatsApp, YouTube, Zoom, Schoology, and Edmodo. Based on the result table 1, it means that Google Classroom is one of the most e-learning application most used by the teacher of history learning. This result is in line with some previous research (Alim, Linda, Gunawan, \& Saad, 2019), who showed that google classroom was effective to used with some challenges. History teachers said that google classroom was easy to used hence, it helped the students to develop their learning. The same statement from Fauzan \& Arifin (2019). The results of their research indicate that google classroom is very effective in increasing students' knowledge, hence it can improve the student learning achievement. Besides, according to Fitriningtiyas, Umamah, \& Sumardi (2019) the quality of history learning will be better if the teacher use google classroom, because it is a media that can make an interesting learning that can combine audio and video.

Table 2. The Teachers' Perception of the Easiness of E-Learning Application

\begin{tabular}{ccccc}
\hline \multicolumn{3}{c}{ Q9 } & & \\
\hline & & Frequency & Percent & $\begin{array}{c}\text { Valid } \\
\text { Percent }\end{array}$ \\
\hline Valid & Disagree & 2 & 11.1 & 11.1 \\
& Agree & 13 & 72.2 & 72.2 \\
& Strongly agree & 3 & 16.7 & 16.7 \\
& Total & 18 & 100.0 & 100.0 \\
\hline
\end{tabular}

Table 2 shows the result of questionnaire number 9: Is the e-learning application that you use are easy to master? Based on the table above, $72.2 \%$ of teachers agree that the elearning application is easy to use by themselves and their students. Their students quickly master the application. For instance, the use of Google Classroom and WhatsApp were very famous and often used by the students. This research had the same results as previous researchers with regard to applications that were easy to use and most often used namely: the first was Rahmawati \& Pamungkas (2020). They found that WhatsApp is the favorite online application. The second was Fauzan \& Arifin (2019). The result showed that Google Classroom was easy delivery by the teachers and easily access by the students. The third was Harjanto \& Sumarni (2019). They showed that Google Classroom was quite easy to use and there's no any difficulties to operate it. 
Table 3 Results of Student's Questionnaire on E-Learning Applications

\begin{tabular}{|c|c|c|c|}
\hline No & Questions & Yes & No \\
\hline 1 & Is the subject matter on the media described in detail? & $72,7 \%$ & $27,3 \%$ \\
\hline 2 & $\begin{array}{l}\text { Is the subject matter on the media broken down from } \\
\text { easy to difficult? }\end{array}$ & $81,8 \%$ & $18,2 \%$ \\
\hline 3 & $\begin{array}{l}\text { Does the subject matter on the media fit the learning } \\
\text { objectives? }\end{array}$ & $81,8 \%$ & $18,2 \%$ \\
\hline 4 & $\begin{array}{l}\text { Is this E-learning application able to present all } \\
\text { components? }\end{array}$ & $63,6 \%$ & $36,4 \%$ \\
\hline 5 & $\begin{array}{l}\text { Does this E-learning application material relate to } \\
\text { previous material that students have learned? }\end{array}$ & $95,5 \%$ & $4,5 \%$ \\
\hline 6 & $\begin{array}{l}\text { Does this E-learning application relate to technological } \\
\text { developments that are happening? }\end{array}$ & $100 \%$ & 0 \\
\hline 7 & $\begin{array}{l}\text { Can the E-learning application provide feedback on } \\
\text { student responses? }\end{array}$ & $77,3 \%$ & $22,7 \%$ \\
\hline 8 & $\begin{array}{l}\text { Are all components in this E-learning application } \\
\text { following the characteristics of the subjects? }\end{array}$ & $90,9 \%$ & $9,1 \%$ \\
\hline 9 & Is the media look attractive? & $86,4 \%$ & $13,6 \%$ \\
\hline 10 & $\begin{array}{l}\text { Do the images displayed on the media make it easy for } \\
\text { you to understand the material? }\end{array}$ & $95,5 \%$ & $4,5 \%$ \\
\hline 11 & $\begin{array}{l}\text { Can it give motivation to the media to increase your } \\
\text { learning motivation? }\end{array}$ & $77,3 \%$ & $22,7 \%$ \\
\hline 12 & $\begin{array}{l}\text { Does the media used involve interactions between you } \\
\text { and the media? }\end{array}$ & $86,4 \%$ & $13,6 \%$ \\
\hline 13 & $\begin{array}{l}\text { Is the information contained in the media fully } \\
\text { explained? }\end{array}$ & $40,9 \%$ & $59,1 \%$ \\
\hline 14 & $\begin{array}{l}\text { Does the language used in the media describe the } \\
\text { density of ideas? }\end{array}$ & $40,9 \%$ & $59,1 \%$ \\
\hline 15 & $\begin{array}{l}\text { Have the events related to the concept of history been } \\
\text { well illustrated? }\end{array}$ & $50,0 \%$ & $50,0 \%$ \\
\hline 16 & $\begin{array}{l}\text { Does this E-learning application motivate you to learn } \\
\text { it? }\end{array}$ & $95,5 \%$ & $4,5 \%$ \\
\hline 17 & Does this E-learning application grow your curiosity? & $95,5 \%$ & $4,5 \%$ \\
\hline
\end{tabular}


18

19
Can this E-learning application improve the quality of your learning?

Is this E-learning application you can master the learning material quickly?
$18,2 \% \quad 81,8 \%$

$63,6 \% \quad 36,4 \%$
Based on the table above, the percentage of student questionnaire scores on instructional media using E-learning method is $100 \%$ to help the students in online learning process (numbers 6 and 26). This statement also supported by Lestiyanawati \& Widyantoro (2020) who stated that by using e-learning, information and elearning applications can help the online learning process.

Besides, $100 \%$ of students choose the 'Yes' option for the question: Does this E-learning application relate to technological developments? This proves that the E-learning application in this study follows the current technological developments following students' needs. It happens because the teachers usually tried to choose e-learning applications that were developing the students' knowledge and keeping the students' active (Harjanto \& Sumarni, 2019). Not only the e-learning application, but also teacher's strategy to encourage interaction and create the material better (Samir Abou El-Seoud, Taj-Eddin, Seddiek, El-Khouly, \& Nosseir, 2014). Therefore, it made students active and attract students' attention in the online learning process. For example, the google classroom application which features sending messages and assignments to teachers and many others.

Besides, $100 \%$ of students choose the 'Yes' option for the question: Does this learning medium help you in the learning process? This shows that the multimedia-based E-learning application allows students in the learning process, such as searching for participant literature. This result is in line with Yanuschik, Pakhomova, \& Batbold (2015), who stated that by using elearning application, the students and teachers can browse material that not only based on the book. Hence, it can help to develop students' knowledge.

Besides, the lowest value of $4.5 \%$ chose the No option (numbers 5.10,16.17 and 22). It can be concluded that students' material in the media is a new material for them. The images displayed in the media support students better know the material provided, motivate students to comprehend the material and increase student curiosity. This result is in line with Harandi (2015) who proved that there was a relationship between e-learning and students' motivation. The media used by the teacher attracts students' attention, therefore students were motivated to take part in the lesson.

Of 25 history teachers who were sent questionnaires, only 18 history teachers filled out the questionnaires. Besides, ten teachers were interviewed. Twenty-two students filled out the questionnaire. The data from the teachers and students helped the researcher to analyses the data. In this discussion, the researcher tried to describe the result of this research.

\section{History Learning During the COVID-19 Pandemic}

History learning experienced differences, and there were also similarities in learning during COVID-19 pandemic (Marharjono, 2020). The difference was that initially, the teacher used faceto-face methods, then online learning changes that rely on internet-based applications (Abidah et al., 2020). Hence, learning tools such as lesson plans also used online lesson plans (Rapanta, Botturi, Goodyear, Guàrdia, \& Koole, 2020). Besides, the material provided was still the same but less, 
most teachers give assignments. The similarity is that the teacher always gave assignments to students. The results of the interview with history teachers were shown below.

The learning carried out as recommended by the government. The difference is only that students do not meet directly with the teacher. The similarity of the material presented is the same as the teaching and learning process activities (Teacher A).

The difference, teachers and students learn online, the material provided is less, mostly giving assignments. The similarity is that students continue to work on tasks as usual (Teacher B).

History teachers faced several obstacles during online learning. The main problem was student participation that was not optimal. This result is in line with Windiarti, Fadilah, Dhermawati, \& Pratolo, (2019) that showed obstacles of e-learning classes. It happened because: first, not all students had facilities such as laptops/computers, smartphones, and internet packages. Second, not all teachers mastered using technology (Jhon, Mustadi, \& Zubaidah, 2020). So, the material given to students was only in the form of text/power points.

Besides, the result of questionnaire number 5 about what form of material do you send to students? Microsoft Word/ PDF, PowerPoint, or learning video? $66.7 \%$ of history teachers used Microsoft Word/ PDF. There were only 16.7\% of history teachers employed learning video and PowerPoint. They rarely made a learning video, and they did not know how to make it. This made students quickly bored, preferably during online learning, teachers should be more creative in providing material and keep interaction to their students (Kim, 2020). For example, by making learning videos and using learning applications such as Google Classroom (Fitriningtiyas et al., 2019) and for presentations, they could use the Zoom application. Third, students' concentration was quickly lost with outside interference when they were at home. Hence back again, the teacher needed to create material and used media that could attract students' learning interests, especially history learning (Sopacua, Fadli, \& Rochmat, 2020). The result of the interview below supported this statement.

There were obstacles in online learning during COVID-19, including:1. Giving assignments simultaneously in each subject; students did not have a package, and there's no internet network connection (Teacher C).

The obstacle was that only about 50\% of the students are active because of the student's uneven internet network (Teacher D).

The obstacles must exist because automatic online learning had to prepare several types of equipment, including smartphones/ laptops, internet network packages. And if these facilities were not available, then automatically could not be done, because not all children have the facilities needed for online learning (Teacher A).

Student learning outcomes in history learning during online learning had also changed. Because many students were not active hence, most students' grades decreased. The average learning value was not like regular learning. But there were also differences of opinion from the history teacher:

The learning outcomes vary, some were increasing, but some were decreasing because of the existing conditions, intelligent students did not have the facilities, making it difficult for them to access learners, making their scores fall. Some were increasing because their parents assisted them in supervising their children studying at home (Teacher B).

If we looked at students' activeness in the learning process carried out online, it was undeniable that the learning outcomes have decreased due to various factors, one of which 
was because learning was carried out online without direct face-to-face. This could reduce students' interest in learning because of the ineffective learning influenced by network disruptions, which often hinder when the learning process was in progress. Hence, the student's concentration became distracted, and student learning's focus became less because of the interference (Teacher D).

Based on the result of interview above, one way to increase the students' outcomes during online learning was using e-learning application. WhatsApp could keep students' interaction and motivation (Susilawati \& Supriyatno, 2020)

During online learning, most students were not disciplined in the teaching and learning process (Virtudazo \& Guhao, 2020). Some of the students were late to log in and not active in the online class. It supported the result of questionnaire number 7: were students disciplined in doing assignments and the following history learning online? $83.3 \%$ of teachers answered No. The students were not disciplined. They were late in doing assignments. Hence, they were late to collect their assignment. It happened because some students have not yet arranged their time well. Some of them did not have a facility like a laptop or a smartphone individually. They could do the assignment after their parents came back from the office. Based on the problems, if the students managed their time and the parents accompany their children in doing assignments, their children would collect the assignment on time.

In terms of doing the assignments that we have given to students, they always worked following the directions and assignments given. However, it was undeniable that not all students could work on assignments according to the specified time. This means that students' discipline had not been fully implemented correctly. Still, a small number of students sometimes did not collect assignments at a predetermined time but exceeded the time that should have been mutually agreed upon (Teacher E).

\section{Students Respond During Study from Home}

There had been a deliberate about online learning among students during the COVID-19 Pandemic. Some students strongly disagreed with online learning. The same result was found by Ro'fah, Hanjarwati, \& Suprihatiningrum (2020). They showed that students prefer face to face learning to online learning. The obstacles of online was the high cost of internet package. Besides, students assumed that they were bored and didn't understand if they only read the material. This result is in line with Yang \& Cornelius, (2004) that showed one of the weakness of online learning is lack of self-regulation and selfmotivation. Present study also showed without directly listening to directions from the teacher, made the students lack of concentration.

Besides, not having facilities such as smartphones or laptops and internet networks that didn't support learning made students lose concentration and motivation to learn. Besides, they miss their teachers and friends. Unlike students who like online learning, some students think they can get more attention from both parents (Janssen et al., 2020). This was because parents always accompanied them when studying online. They could get more rest and save pocket money and didn't need to go to school. Some of the result of the interview with students:

There were many comments to students who liked it with this online learning and did not like it. From students related to online learning that was carried out, most students complained about online learning because not all had sufficient parents. We all knew that internet data packages were one of the most essential things to support the learning process 
carried out and the effectiveness of studying (Teacher F).

Some were happy because learning from home could be freer, and some were not because they might also be bored living at home. They wanted to study with their friends at school. Moreover, students were sometimes confused by just reading without any explanation (Teacher D).

Besides, the questionnaire results showed a positive response to the use of the e-learning application used by their teachers during online learning. This could be seen from Table 3.86.4\% of students chose the Yes option to answer the question: Is the media look attractive? This showed that students like the appearance of the media used. $95.5 \%$ of students argued that images displayed on the media made it easy for them to understand the material. Besides, 95.5\% of the E-learning application motivated students to learn the material. This was also supported by the results of interviews with student B:

The e-learning application that my teacher used was Google Classroom, which had helped me and my friends and teachers learn online and interact during the COVID19 Pandemic. But unfortunately, the teacher only provided material in the form of pdf and assignments every day (Student B).

Looking at student responses, researchers could conclude that the e-learning application used has helped during the online learning process. History eachers just needed to be more creative in designing their learning materials, especially history learning (Sastranegara, Suryo, \& Setiawan, 2020). It was better if the teacher could design learning that included pictures and videos and is supported by the teacher's voice or, in other words, by making learning videos. Only "voice" could be fully operated when a class is switched to online education because body language and facial expressions are limited by their difficult use by the screens (Bao, 2020). This learning video could later be shared with students using the e-learning application that they have used, either using Google Classroom or WhatsApp. Teachers needed increasing knowledge and mastery of teachers in utilizing technology.

Moreover, 68.2\% chose No for the question: Does this E-learning application make it easier for you to understand the subject matter without other sources? It could be concluded that e-learning applications are only used as media for teachers and students in online learning. Teachers also needed to give materials and also feedback to their students.

The trending topic about online learning that was carried out apart from the student concerned who followed the teaching and the teacher who directed the learning process was also parents figure who was the assessment team of the learning process at home. This result is in line with Janssen et al., (2020) that showed the parents also help the students with school. Because of work from home, the parents had many times at home to accompany their children at home. With the collaboration between teachers and parents, the online learning process can be carried out and the learning objectives can be maximally achieved.

Most parents help their children to This could be a daunting job (Spinelli, Lionetti, Pastore, $\&$ Fasolo, 2020). Some of the parents complained about this online learning process. The parents with various complaints, the parents felt unprepared to become teachers for their children at home. This was because not all parents know the lessons of their children was working on. Besides, including complaining about the tasks given to their children, and the costs they had to spend to buy an internet data package. They had to buy a data package in a month, up to 2 or 3 times, which was usually only once a month, had now changed to many times as usual. Indeed, 
the same finding was noticed that the challenge here is access to the Internet and numerous students' financial potential (Allo, 2020). Anyone can afford to purchase a data plan on the Internet; others may not even buy it. These statements were supported by the result of interviews with the teacher.

There were parents who were happy and unhappy. Because parents had to provide online learning facilities for their children. Financially capable parents did not worry, but some parents were not well off financially. They complained because they felt that their children lack learning facilities such as laptops or smartphones. Besides, parents also had to control their child's learning at home (Teacher G).

The response of parents in online learning was in this learning, the value was still not optimal compared to face-to-face learning that was done as usual before there was COVID-19. Parents who worked in the morning and came home at night felt it is challenging to learn online. Parents were burdened with the material at school because they had to help with their child's duties (Teacher H).

\section{E-learning Applications Are Most Often Used During Study from Home}

Based on the results of questionnaires given to history teachers regarding the e-learning applications that they most often used during online learning were Google Classroom and WhatsApp. This result is in line with Mulatsih (2020) and Marharjono, (2020) that showed teachers and students think that Google classroom was not only a free application but also this application was very easy to use.

Google Classroom had a beneficial feature in the online learning process, namely: the teacher could send assignments to students by setting a schedule for assignment limits (Alim et al., 2019); students were trained in discipline to do assignments; teachers could immediately give value to student work results (Fauzan \& Arifin, 2019); students could interact with friends and teachers, and teachers could provide feedback to students either individually or in public (Marharjono, 2020).

The Google Classroom application was very easy to use and easy for students to master. Teachers and students could access the classroom using either a smartphone or a laptop. The only problem was if you didn't have an internet package. You can't access it (Teacher J).

Besides, the teacher also chose WhatsApp as an e-learning application which was widely used by history teachers in this research. They thought that WhatsApp is useful in the online learning process (Mulyadi, 2020), for example, teachers and students used to interact with each other through WhatsApp groups. Teachers could send students in the form of pictures, videos, documents, or voice notes to students (Qamar, Riyadi, \& Wulandari, 2019). This application's drawback was that the teacher was rather complicated in filing student assignments because the files were scattered in the chat room. Moreover, the teacher could not directly give a grade to student work. This was very different from the Google Classroom application, which had the assignment feature (Alim, Linda, Gunawan, \& Saad, 2019).

\section{CONCLUSIONS}

The condition of history class through online learning is different from face to face learning. Conducting online learning, the teachers design the class by using some applications which are free, and easy to use. Especially in history class, the most teachers used Google Classroom and WhatsApp in teaching history. Meanwhile, some 
students still face some problems to join the class such as the package of internet or sometimes the internet connection is not good; and also students do not have smart phone or laptop. Suggestions before conducting online learning, the teachers and the students should master with the e-learning application that will be used. Besides the teachers also need to encourage the materials, and know the strategy to motivate students.

\section{- REFERENCES}

Abidah, A., Hidaayatullaah, H. N., Simamora, R. M., Fehabutar, D., \& Mutakinati, L. (2020). The Impact of Covid-19 to Indonesian Education and Its Relation to the Philosophy of "Merdeka Belajar." Studies in Philosophy of Science and Education, 1(1), 38-49.

Adnan, M., \& Anwar, K. (2020). Online learning amid the COVID-19 pandemic: Students perspectives. Journal of Pedagogical Research, 1(2), 45-51.

Alim, N., Linda, W., Gunawan, F., \& Saad, M. S. M. (2019). The effectiveness of Google classroom as an instructional media: Acase of state islamic institute of Kendari, Indonesia. Humanities and Social Sciences Reviews, 7(2), 240-246.

Allo, M. D. G. (2020). Is the online learning good in the midst of Covid-19 Pandemic/? The case of EFL learners. Jurnal Sinestesia, 10(1), 1-10. Retrieved from https:// ejournal.undiksha.ac.id/index.php/JPP/ article/view/24964

Anggraeni, A. R., \& Suharso, R. (2019). Keragaman Media Pembelajaran Yang Digunakan Guru Sejarah Dalam Pembelajaran Sejarah Sekolah Menengah Atas Negeri Di Kabupaten Rembang Tahun Ajaran 2018/2019. Indonesian Journal of History Education, 7(1), 5966.
Bao, W. (2020). COVID 19 and online teaching in higher education: A case study of Peking University . Human Behavior and Emerging Technologies, 2(2), 113-115.

Besand, A. (2020). The crisis as an opportunity to learn. Or: 'collateral civic education' in the context of the covid-19 pandemic an essay in times of crises. In Journal of Social Science Education (Vol. 19).

Cresswell, J. W., Plano Clark, V. L., Gutmann, M. L., \& Hanson, W. E. (2003). Research Design: Qualitative, Quantitative, and Mixed Methods Approaches. In A. Tashakkori \& C. Teddle (Eds.), Handbook of Mixed Methods in Social and Behavioral Research (pp. 209-240). Thousand Oaks, CA: Sage.

Creswell, J. W. (2012). Educational Research: Planning, Conducting, and Evaluating Quantitative and Qualitative Research. Boston: Pearson Education, Inc.

Dhawan, S. (2020). Online Learning: A Panacea in the Time of COVID-19 Crisis. Journal of Educational Technology Systems, 49(1), 5-22.

Fauzan, F., \& Arifin, F. (2019). The Effectiveness of Google Classroom Media on the Students' Learning Outcomes of Madrasah Ibtidaiyah Teacher Education Department. Al Ibtida: Jurnal Pendidikan Guru MI, 6(2), 271.

Fitriningtiyas, D. A., Umamah, N., \& Sumardi. (2019). Google classroom: As a media of learning history. IOP Conference Series: Earth and Environmental Science, 243(1).

Fund, U. N. C. (2020). COVID-19 and Children in Indonesia. COVID-19 and Children in Indonesia, (11 May). Retrieved from https://www.unicef.org/indonesia/sites/ unicef.org.indonesia/files/2020-05/ COVID-19-and-Children-in-Indonesia- 
2020_0.pdf

Hamiti, M., \& Reka, B. (2012). Teaching with technology. Procedia - Social and Behavioral Sciences, 46, 1171-1176.

Hapsari Sinta Maulida, Sugito, P. Y. F. (2020). Jurnal Pendidikan Progresif Parent's Involvement in Early Childhood Education during the Covid-19. Jurnal Pendidikan Progresif, 10(2), 298-311.

Harandi, S. R. (2015). Effects of e-learning on Students' Motivation. Procedia - Social and Behavioral Sciences, 181, 423-430.

Harjanto, A. S., \& Sumarni, S. (2019). Teacher's Experiences on The Use of Google Classroom. 3rd English Language and Literature International Conference (ELLiC), 3, 172-178.

Huang, R. H., Liu, D. J., Amelina, N., Yang, J. F., Zhuang, R. X., Chang, T. W., \& Cheng, W. (2020). Guidance on Active Learning at Home during Educational Disruption/: Promoting student's selfregulation skills in COVID-19 outbreak. Beijing. Retrieved from https:// iite.unesco.org/wp-content/uploads/2021/ 01/Guidance-on-Active-Learning-atHome-in-COVID-19-OutbreakSLIBNU-V2.0_2020501.pdf

Janssen, L. H. C., Kullberg, M. L., Verkuil, B., van Zwieten, N., Wever, M. C. M., van Houtum, L. A. E. M., ... Elzinga, B. M. (2020). Does the COVID-19 pandemic impact parents' and adolescents' wellbeing? An EMA-study on daily affect and parenting. PLoS ONE, 15(10 October), $1-21$.

Jhon, W., Mustadi, A., \& Zubaidah, E. (2020). Jurnal Pendidikan Progresif Online Learning during Covid-19 Pandemic in Developing Countries/: Does it run well/ ? 10(3), 440-454.

Kim, J. (2020). Learning and Teaching Online
During Covid-19: Experiences of Student Teachers in an Early Childhood Education Practicum. International Journal of Early Childhood, 52(2), 145-158.

Lestiyanawati, R., \& Widyantoro, A. (2020). Strategies and Problems Faced by Indonesian Teachers in Conducting ELearning System During COVID-19 Outbreak. Journal of Culture, Literature, Linguistic and English Teaching, 2(1), 71-82. Retrieved from https://ojs.unsiq.ac.id/index.php/cllient/ article/view/1271

Marharjono, M. (2020). Benefits of Learning History Using Google Classroom at the Covid-19 Pandemic Period. Ideguru: Jurnal Karya Ilmiah Guru, 5(1), 56-.

Mulatsih, B. (2020). Application of Google Classroom, Google Form and Quizizz in Chemical Learning During the Covid-19 Pandemic. Ideguru: Jurnal Karya Ilmiah Guru, 5(1), 16-.

Mulyadi, E. (2020). Online Physics Learning Via WhatsApp, Google Form, and Email in the Achievement of Active Presence and Student Learning Outcomes. Ideguru: Jurnal Karya Ilmiah Guru, 5(1), 34-.

Prastowo, N. D., In, B., \& Suryadi, A. (2019). Pengaruh Penggunaan Media Komik Sejarah Terhadap Minat Belajarsiswa Kelas Xi Ips Di Sma Negeri 1 Cepogo Tahun Pelajaran 2018/2019 Pokok Bahasan Kerajaan Singhasari. Indonesian Journal of History Education, 7(1), 3339.

Priatna, T., Maylawati, D. S. adillah, Sugilar, H., $\&$ Ramdhani, M.A. (2020). Key success factors of e-learning implementation in higher education. International Journal of Emerging Technologies in Learning, 15(17), 101-114.

Qamar, K., Riyadi, S., \& Wulandari, T. C. 
(2019). Utilization of whatsapp application

as discussion media in blended learning. Journal of Education and Learning (EduLearn), 13(3), 370.

Rahmawati, A., \& Pamungkas, B. T. T. (2020). Mapping the Favorite Online Learning Application and Method During the Covid19 Pandemic Period. International Joint Conference on Arts and Humanities (IJCAH 2020), 491(Ijcah), 264-268.

Rapanta, C., Botturi, L., Goodyear, P., Guàrdia, L., \& Koole, M. (2020). Online University Teaching During and After the Covid-19 Crisis: Refocusing Teacher Presence and Learning Activity. Postdigital Science and Education, 2(3), 923-945.

Ratri, S. D., Bain, \& Amin, S. (2017). Pengaruh Penggunaan Media Pembelajaran Sejarah Indonesia E- Learning Berbasis Quipper School Terhadap Minat dan Hasil Belajar Siswa Kelas X SMK N 04 Kendal Tahun Pelajaran 2016/2017. Indonesian Journal of History Education, 5(2), 6067.

Ro'fah, R., Hanjarwati,A., \& Suprihatiningrum, J. (2020). Is Online Learning Accessible During COVID-19 Pandemic? Voices and Experiences of UIN Sunan Kalijaga Students with Disabilities. In Nadwa (Vol. 14).

Samir Abou El-Seoud, M., Taj-Eddin, I. A. T. F., Seddiek, N., El-Khouly, M. M., \& Nosseir, A. (2014). E-learning and students' motivation: A research study on the effect of e-learning on higher education. International Journal of Emerging Technologies in Learning, 9(4), 20-26.

Sastranegara, T., Suryo, D., \& Setiawan, J. (2020). A Study of the Use of Quipper School in History Learning during COVID-19 Pandemic Era. International Journal of Learning and Development,
10(3), 20.

Sopacua, J., Fadli, M. R., \& Rochmat, S. (2020). The history learning module integrated character values. Journal of Education and Learning (EduLearn), 14(3), 463.

Spinelli, M., Lionetti, F., Pastore, M., \& Fasolo, M. (2020). Parents' Stress and Children's Psychological Problems in Families Facing the COVID-19 Outbreak in Italy. Frontiers in Psychology, 11(January), 17.

Susilawati, S., \& Supriyatno, T. (2020). Online Learning Through WhatsApp Group in Improving Learning Motivation in the Era and Post Pandemic COVID -19. Jurnal Pendidikan, 5(6), 852-859.

Torrau, S. (2020). Exploring teaching and learning about the corona crisis in social studies webinars: A case study. Journal of Social Science Education, 19(Special Issue 1), 15-29.

Valverde-Berrocoso, J., del Carmen GarridoArroyo, M., Burgos-Videla, C., \& Morales-Cevallos, M. B. (2020). Trends in educational research about e-Learning: A systematic literature review (20092018). Sustainability (Switzerland), 12(12).

Virtudazo, M. C. A., \& Guhao, E. S. (2020). Student discipline in the classroom: Public school teachers' point of view. International Journal of Scientific and Technology Research, 9(1), 271-282.

Windiarti, S., Fadilah, N., Dhermawati, E., \& Pratolo, B. W. (2019). Teachers' Perception toward the Obstacles of ELearning Classes. Ethical Lingua: Journal of Language Teaching and Literature, 6(2), 117-128.

Yang, Y., \& Cornelius, L. F. (2004). Students' Perceptions towards the Quality of Online Education: A Qualitative Approach. 
26 | Jurnal Pendidikan Progresif, Vol. 11, No. 1, pp. 12-26, April 2021

Association for Educational

Communications and Technology, 861877. Chicago.

Yanuschik, O. V., Pakhomova, E. G., \& Batbold, K. (2015). E-learning as a Way to Improve the Quality of Educational for International Students. Procedia - Social and Behavioral Sciences, 215(June), 147155.

Yulandari, E. S. (2020). Students' Perception on Daring Learning While Quarantine: a Qualitative Case Study. Journal of Languages and Language Teaching, $8(3), 315$.

Zaharah, Kirilova, G. I., \& Windarti, A. (2020). Impact of Corona Virus Outbreak Towards Teaching and Learning Activities in Indonesia. SALAM; Jurnal Sosial \& Budaya Syar-I, 7(3), 269-282.

Zahro, M., Sumardi, \& Marjono. (2017). The Implementation Of The Character Education In History Teaching. Jurnal Historica, 1(2252), 1-11. 